\title{
Chronic obstructive pulmonary disease and cardiovascular comorbidity
}

\begin{abstract}
Chronic obstructive respiratory disease (COPD) is considered as systemic pathology with multiple systemic effects that define patients' prognosis and quality of life. Smoking plays a significant part in COPD pathogenesis. Chronic exposure of tobacco smoking (TS) is integral agent between topical changes of bronchopulmonary system and systemic proinflammatory activation with development of oxidative stress, endothelial dysfunction and progressing damage of target organs. The connection of COPD and some cardiovascular and cerebrovascular diseases with atherosclerotic vascular damage has been estimated in our days. Atherosclerosis of cerebral arteries also might be both the reason of chronic brain ischemia and a sign of severe alterations in brain blood circulation. TS may predispose individuals to atherogenic and thrombotic problems, significantly increasing the risk for ischemic manifestations such as acute coronary syndrome and stroke. At another side chronic smokers have a higher incidence of small vessel ischemic disease, a pathological condition characterized by leaky brain microvessels and loss of blood-brain barrier (BBB) integrity. Cigarette smoking is a notable influencing factor for matrix metalloproteinases (MMPs) elevation. MMPs are a family of endopeptidases that degrade extracellular matrix proteins, play a pivotal role in tissue remodeling, and participate in a variety of physiological and pathological processes. One of the members of the MMP family, MMP-9, is a gelatinase that has been implicated in the pathogenesis of atherosclerosis and chronic obstructive pulmonary disease. MMPs are critical for tissue formation, neuronal network remodeling, and blood-brain barrier integrity in the brain.
\end{abstract}

Keywords: chronic obstructive pulmonary disease, tobacco smoking, atherosclerosis, matrix metalloproteinases, brain, cardiovascular risk
Volume 5 Issue I - 2018

\author{
Zakharchuk N, Nevzorova V, Brodskaya T, \\ Gonchar E \\ Department of Therapy, Pacific State Medical University, Russia
}

Correspondence: : Natalia Zakharchuk, Therapy department, Pacific State Medical University, Ostryakovast 2,Vladivostok, Russia, Tel 8323245 1702; Fax 8323245 I702; Email zaharchuknat@mail.ru

Received: December 18, 2017 | Published: January 09, 2018
Abbreviations: $\mathrm{BBB}$, blood-brain barrier; $\mathrm{CCA}$, common carotid artery; CIMT, carotid intima-media thickness; COPD, chronic obstructive pulmonary disease; FEV1, forced expiratory volume in 1 second; LDL, low density lipoprotein; MMPS, matrix metalloproteinases; SCORE Scale, scale of systematic coronary risk evaluation; TIMPs, tissue inhibitors of matrix metalloproteinases; TS, tobacco smoke

\section{Introduction}

There is an ongoing search for general risk factors and development mechanisms of cardiovascular and cerebrovascular pathology in COPD in our days. COPD is an independent risk factor for cardiovascular diseases, a large part of deaths in patients with COPD is associated with atherosclerosis and cardiovascular diseases. ${ }^{1,2}$ An important indicator of atherosclerosis is the carotid intima-media thickness (CIMT) measurement and increasing of atherosclerotic plaques. These indicators are markers of high risk of ischemic heart disease and stroke progress, as shown by the data in the Cardiovascular Health Study and Rotterdam Study. ${ }^{3}$ Realization of different imaging methods has significantly extended the horizons of atherosclerosis diagnostics. Ultrasound scanning of cerebral vessels is characterized by extensive information, non-invasiveness, availability and relatively low cost. This method allows to get information about structural characteristics of atherosclerotic plaques, velocity and spectral parameters of the blood flow. ${ }^{4}$

Previous studies have demonstrated that CIMT was increased and correlated with the severity of airflow obstruction in patients with COPD. Increasing the CIMT can be caused by hypoxia, systemic inflammation and endothelial dysfunction in COPD, but not by traditional coronary atherosclerosis. ${ }^{5}$ Smokers with reduced air flow have a more significant subclinical atherosclerosis according to the Iwamoto et al. report. FEV1 was independently associated with CIMT. ${ }^{6}$ More other low FEV1 was found to be associated with increased CIMT in the ARIC Study and MESA Lung Study. ${ }^{7}$ Lahousse et al. ${ }^{7}$ showed that patients with COPD had a twofold increased risk of having carotid wall thickening compared with persons with normal lung function.

The damage of $\mathrm{BBB}$ is one of major factor which promotes cerebrovascular accidents during COPD and smoking patients. Condition of MMPs is a principal role of it is dysbalance. Matrix metalloproteinases (MMPs) are multifunctional endopeptitases playing a key role in certain physiological (angiogenesis, morphogenesis, remodeling of neural and capillary networks) and pathological processes of a brain. ${ }^{9}$ Causing ZO-1 proteolysis in endothelium and basal membrane destruction, they increase penetrability of the blood-brain barrier (BBB), contribute to swelling and inflammation processes, thus, enlarging the scope of the nervous tissue damage. Tissue concentration of MMPs depends on both gene expression level, and potency of tissue inhibitors - TIPMs. ${ }^{10}$ Apart from TIMP, excessive expression of metalloproteinases might be suppressed by heparin supplied from mast cells of the tunica externa or perivascular nervous tissue, as well as glucocorticoid, estrogen, progesterone. There areincreasing of MMP-2/MMP-9 expression and TIMP-1/TIMP-2 reduction in all elements of neurovascular units: capillary endotheliocytes, neurons, macroglial cells in case of the ischemic stroke. ${ }^{11}$ 


\section{Discussion}

\section{Carotid arteries condition in COPD}

The measurement of CIMT and atherosclerotic plaques is used for risk stratification of cardiovascular diseases (CVD). According to the data of ultrasound duplex scanning, there is thickening of intimamedia complex in the majority of COPD and smoking patients. Some papers present convincing data on direct connection between COPD patients with carotid atherosclerosis and forced expiratory flow during spirometry. ${ }^{5-7}$ Similar to previous studies, we also found a higher CIMT in patients with COPD in our study (Table 1). Apart from that, atherosclerotic plaques in the common carotid artery (CCA) bifurcation area and internal carotid artery are established at all patients of COPD. However the frequency of their occurrence depends on GOLD degree (Table 1). So, at GOLD I, II and the III degree of a plaque are revealed respectively at $33.3 \%, 59.3 \%$ and $76.2 \%$ of patients, and at GOLD IV degree they are found in all patients. Identification of atherosclerotic plaques in carotids is unconditional confirmation of existence of subclinical atherosclerosis and indicates high risk of development of cardiovascular complications. The COPD patients are more likely to have unstable atherosclerotic plaques with big lipid nuclei. These changes are visible even in patients with a mild case of COPD. Lahousse et al. ${ }^{7}$ have discovered that atherosclerotic plaques are very common for COPD in $60 \%$ of non-smoking patients and $80 \%$ of smokers. ${ }^{7}$ Atherosclerotic plaques in case of COPD have a high risk of rupture even for patients with a very mild case of airway obstruction, while smoking only increases that risk. ${ }^{12}$ Unstable atherosclerotic plaques with big lipid nuclei appear early in COPD and explain the doubling of mortality rates from cardiovascular diseases in this group of patients. ${ }^{13}$ Animal tests show that systemic inflammation in COPD releases pro-inflammatory mediators that facilitate inflammatory cells migration into atherosclerotic plaques, increasing the level of lipids there and, thus creating unstable plaques. ${ }^{14}$

Table I The clinical characteristic of the patients.

\begin{tabular}{|c|c|c|c|c|c|}
\hline Parameters & $\begin{array}{l}\text { Control group } \\
(n=20)\end{array}$ & $\begin{array}{l}\text { COPD }(n=75) \\
\text { GOLD I }(n=18)\end{array}$ & $\begin{array}{l}\text { GOLD II } \\
(n=27)\end{array}$ & GOLD III (n=2I) & GOLD IV (n=9) \\
\hline \multicolumn{6}{|c|}{ Clinical characteristic of the patients } \\
\hline Age & $\begin{array}{l}54.05 \\
(52.12-55.98)\end{array}$ & $\begin{array}{l}58.83 \\
(56.03-61.64)\end{array}$ & $\begin{array}{l}52.67 \\
(48.79-56.54)\end{array}$ & $\begin{array}{l}62.71 \\
(59.8-65.63)\end{array}$ & $\begin{array}{l}59.33 \\
(56.64-62.02)\end{array}$ \\
\hline Female, abs. (\%) & & $12(66.7 \%)$ & $6(22.2 \%)$ & 15 (7I.4\%) & $6(66.7 \%)$ \\
\hline Male, abs. (\%) & $9(45 \%)$ & $6(33.3 \%)$ & $2 \mathrm{I}(77.8 \%)$ & $6(28.6 \%)$ & $3(33.3 \%)$ \\
\hline $\mathrm{BMI}, \mathrm{kg} / \mathrm{M}^{2}$ & $\begin{array}{l}24 \\
(23.15-24.85) \\
93.33\end{array}$ & $\begin{array}{l}24.51 \\
(23.69-25.33) \\
97.17\end{array}$ & $\begin{array}{l}27.4 \\
(25.53-29.27) \\
98.9\end{array}$ & $\begin{array}{l}27.09 \\
(24.77-29.41) \\
97.83\end{array}$ & $\begin{array}{l}24.47 \\
(23.68-25.25) \\
97\end{array}$ \\
\hline WSfemale, sm & $\begin{array}{l}(91.37-95.29) \\
80.91 \\
(78.33-83.48)\end{array}$ & $\begin{array}{l}(95.94-98.39) \\
81.83 \\
(79.54-84.13)\end{array}$ & $\begin{array}{l}(95.91-101.9) \\
88.83 \\
(75.55-102.11)\end{array}$ & $\begin{array}{l}(95.23-100.4) \\
87.67 \\
(81.08-94.25)\end{array}$ & $\begin{array}{l}(94.52-99.48) \\
84 \\
(81.35-86.65)\end{array}$ \\
\hline $\begin{array}{l}\text { Post-BD FEV }, \% \\
\text { (in combination with a } \\
\text { FEVI/FVC }<70 \% \text { ) }\end{array}$ & $\begin{array}{l}91.85 \\
(88.65-95.05)\end{array}$ & $\begin{array}{l}86.5 \\
(85.38-87.62)\end{array}$ & $\begin{array}{l}66.15 \\
(64.52-67.77)\end{array}$ & $\begin{array}{l}49.29 \\
(46.52-52.05)\end{array}$ & $\begin{array}{l}26.22 \\
(25.02-27.42)\end{array}$ \\
\hline Smokers, abs. (\%) & - & $12(66.7 \%)$ & 24 (88.9\%) & $12(57.1 \%)$ & $6(66.7 \%)$ \\
\hline Smoking history, pack-year & - & $\begin{array}{l}27.5 \\
(18.77-36.23)\end{array}$ & $\begin{array}{l}37.63 \\
(31.05-44.2)\end{array}$ & $\begin{array}{l}52.5 \\
(39.19-65.81)\end{array}$ & $\begin{array}{l}74 \\
(50.66-97.34)\end{array}$ \\
\hline \multicolumn{6}{|l|}{ Lipidogram } \\
\hline $\begin{array}{l}\text { Totalcholesterol, } \\
\mathrm{mmol} / \mathrm{l}\end{array}$ & $\begin{array}{l}5.06 \\
(4.8-5.32) \\
2.92\end{array}$ & $\begin{array}{l}5.39 \\
(5.11-5.68) \\
3.23\end{array}$ & $\begin{array}{l}5.5^{*} \\
(5.19-5.81) \\
3.42^{*}\end{array}$ & $\begin{array}{l}5.69 * \\
(5.43-5.95) \\
3.48^{*}\end{array}$ & $\begin{array}{l}5.48^{*} \\
(5.21-5.74) \\
3.3^{*}\end{array}$ \\
\hline $\begin{array}{l}\mathrm{LDL}, \mathrm{mmol} / \mathrm{l} \\
\mathrm{HDL}, \mathrm{mmol} / \mathrm{l}\end{array}$ & $\begin{array}{l}(2.67-3.17) \\
1.17 \\
(1.07-1.27) \\
1.33 \\
(1.16-1.5)\end{array}$ & $\begin{array}{l}(3-3.47) \\
1.14 \\
(1.03-1.26) \\
1.45 \\
(1.28-1.62)\end{array}$ & $\begin{array}{l}(3.18-3.67) \\
1.12 \\
(1.04-1.21) \\
1.67^{*} \\
(1.51-1.82)\end{array}$ & $\begin{array}{l}(3.21-3.75) \\
1.13 \\
(1.02-1.25) \\
1.61^{*} \\
(1.4-1.82)\end{array}$ & $\begin{array}{l}(3.13-3.47) \\
1.07 \\
(0.97-1.16) \\
1.26 \\
(1.12-1.39)\end{array}$ \\
\hline \multicolumn{6}{|c|}{ Parameters of ultrasound scanning } \\
\hline CIMT of right CCA, MM & $\begin{array}{l}0.81 \\
(0.73-0.89) \\
0.79 \\
(0.7-0.88)\end{array}$ & $\begin{array}{l}0.98^{*} \\
(0.88-1.08) \\
1.01 * \\
(0.93-1.08)\end{array}$ & $\begin{array}{l}0.96 * \\
(0.86-1.05) \\
0.97 * \\
(0.88-1.06)\end{array}$ & $\begin{array}{l}I .1 I^{*} \\
(1.03-1.2) \\
1 . I^{*} \\
(1.02-1.18)\end{array}$ & $\begin{array}{l}1.17^{*} \\
(1.05-1.28) \\
1.13^{*} \\
(1.04-1.23)\end{array}$ \\
\hline $\begin{array}{l}\text { Increase CIMT, } \\
\text { number of people (\%) }\end{array}$ & $5(25 \%)$ & $12(66.7 \%)$ & $18(66.7 \%)$ & $21(100 \%)$ & $9(100 \%)$ \\
\hline $\begin{array}{l}\text { ASP, } \\
\text { numberofpeople (\%) }\end{array}$ & - & $6(33.3 \%)$ & $16(59.3 \%)$ & $18(76.2 \%)$ & $9(100 \%)$ \\
\hline
\end{tabular}

*: $\mathrm{p}<0.05$ Compared to the Control Group; BMI, body mass index;WS, waist circumference; Post-BD FEVI, post-bronchodilator forced expiratory volume in one second (FEVI); FVC, forced vital capacity; HDL, high-density lipoprotein; LDL, low-density lipoprotein; CIMT, carotid intima-media thickness; CCA, common carotid artery; asp, atherosclerotic plaque 
Exposure to smoke induces a significant thickening of intimamedia complex in conductance arteries, atherosclerotic plaques in the CCA bifurcation area and internal carotid artery mouth that leads to partial artery stenosis. ${ }^{15}$ Long-term exposure to toxic products of tobacco combustion causes hypertrophy of smooth muscle cells, disorganization of arterial myoelastic tissue, faster lipid peroxidation leading to thickening of vessel walls, deterioration of their mechanic properties and atherogenesis. ${ }^{16,17}$ It results in the lower level of arterial elasticity, excessive rigidity of vessel walls with accompanying loss of their damping properties in response to fluctuations of systemic arterial pressure and other effects of situational hemodynamic stresses, thus, increasing the risk of arterial hypertension and worsening the prognosis for the course of the disease. ${ }^{18}$

The correlation between a subclinical atherosclerosis and such traditional risk factors as a sex, smoking, level of cholesterin, triglycerides, LDL, the body mass index, waist circumference and blood pressure is established (Table 2). Using of SCORE scale for assessment of cardiovascular risk was insufficiently informative at COPD, especially in groups of low and moderate risk. Ultrasound visualization of carotid arteries is necessary for specification of degree of cardiovascular risk at these patients. Atherosclerotic plaques in carotid arteries are found more, than in a half of patients with low and moderate cardiovascular risk. It is unconditional confirmation of an atherosclerosis and demands change of degree of risk on higher. We found that the greatest correlation is detected with a decrease in FEV1 at COPD III-IV level with traditional risk factors in the analysis of other possible factors. (Analyzing other possible factors, we have found out that the greatest correlation is revealed not so much with traditional risk factors, how many with extent of reduction of FEV1 at the level of COPD III-IV).

Table 2 Risk factors and atherosclerosis.

\begin{tabular}{|c|c|c|}
\hline Risk factor & $\begin{array}{l}\text { Hazard ratio } \\
\text { ( } 95 \% \text { confidence interval) }\end{array}$ & p-Level \\
\hline Male & $\begin{array}{l}\text { I.32 } \\
(95 \% \mathrm{Cl}: \mathrm{I} .05-\mathrm{I} .66)\end{array}$ & $\mathrm{p}<0.05$ \\
\hline Female & $\begin{array}{l}0.8 \\
(95 \% \mathrm{Cl}: 0.59-0.95)\end{array}$ & $\mathrm{p}<0.05$ \\
\hline Smoking & $\begin{array}{l}\text { I.I } \\
\text { (95\% Cl: } 0.78-1.48)\end{array}$ & $\mathrm{p}<0.05$ \\
\hline Hypertension & $\begin{array}{l}2.9 \\
(95 \% \mathrm{Cl}: 1.45-5.67)\end{array}$ & $\mathrm{p}<0.05$ \\
\hline $\begin{array}{l}\mathrm{FEV}_{1} \geq 80 \% \\
\text { (in combination with a } \\
\mathrm{FEV}_{1} / \mathrm{FVC}<70 \% \text { ) }\end{array}$ & $\begin{array}{l}2.2 \\
(95 \% \mathrm{Cl}: 1.05-4.68)\end{array}$ & $\mathrm{p}<0.05$ \\
\hline FEV, $60-80 \%$ & $\begin{array}{l}1.9 \\
(95 \% \mathrm{Cl}: 1.09-3,35)\end{array}$ & $\mathrm{p}<0.05$ \\
\hline FEV, $30-60 \%$ & $\begin{array}{l}8,6 \\
(95 \% \mathrm{Cl}: 1.22-60.07)\end{array}$ & $\mathrm{p}<0.05$ \\
\hline $\mathrm{FEV}_{1}<30 \%$ & $\begin{array}{l}\text { II.5 } \\
(95 \% \mathrm{Cl}: \text { I.7I - 77.5) }\end{array}$ & $\mathrm{p}<0.05$ \\
\hline
\end{tabular}

Table Continued

\begin{tabular}{|c|c|c|}
\hline Risk factor & $\begin{array}{l}\text { Hazard ratio } \\
\text { ( } 95 \% \text { confidence interval) }\end{array}$ & p-Level \\
\hline Increase of BMI & $\begin{array}{l}\text { I } \\
(95 \% \mathrm{Cl}: 0.83-1.30)\end{array}$ & $\begin{array}{l}p>0.05 \\
(\text { нд) }\end{array}$ \\
\hline Abdominalobesity & $\begin{array}{l}\text { I.5 } \\
(95 \% \mathrm{Cl}: 1-00-2.10)\end{array}$ & $\mathrm{p}<0.05$ \\
\hline $\begin{array}{l}\text { Hight level of total } \\
\text { cholesterol }\end{array}$ & $\begin{array}{l}2 . \mathrm{I} \\
(95 \% \mathrm{Cl}: \mathrm{I} . \mathrm{I} 2-3.8 \mathrm{I})\end{array}$ & $\mathrm{p}<0.05$ \\
\hline Hight level of LDL & $\begin{array}{l}2.2 \\
(95 \% \mathrm{Cl}: 1.29-3.75)\end{array}$ & $\mathrm{p}<0.05$ \\
\hline Low level of HDL & $\begin{array}{l}0,9 \\
(95 \% \mathrm{Cl}: 0.7 \mathrm{I}-\mathrm{I} .15)\end{array}$ & $\begin{array}{l}P>0.05 \\
(\text { нд) }\end{array}$ \\
\hline $\begin{array}{l}\text { Hight level of } \\
\text { triglycerides }\end{array}$ & $\begin{array}{l}14 \\
(95 \% \mathrm{Cl}: \mathrm{I} .14-1.7 \mathrm{I})\end{array}$ & $\mathrm{p}<0.05$ \\
\hline
\end{tabular}

FEV , forced expiratory volume in one second; BMI, body mass index; HDL, high-density lipoprotein; LDL, low-density lipoprotein

\section{Matrix metalloproteinases and their tissue inhibitors in the cerebral arteries at chronic smoking}

Dysregulation caused by the disrupted balance between metalloproteinases and their endogenous inhibitors stimulates destruction of extracellular matrix, thus, increasing risk of damage of $\mathrm{BBB}$ at the cerebrovascular diseases. ${ }^{19}$ Accelerated degradation of extracellular matrix in case of different diseases is a result of a complex chain of reactions that apart from MMP-2 have many other metalloproteinases (MMP-3, MMP-7, MMP-9, MMP-14, MTMMP-1, etc.) with synergetic functioning. ${ }^{20}$ All of them correlate with specific receptors and define changes of different extracellular matrix components, including basal membranes of cellular capillaries, this way damaging BBB penetrative qualities and promoting stroke development that is one of the most frequent complications of the arterial hypertension and other risk factors.

We have studied the contents of MMPS and TIMPs in cerebral vessels at the persons with anamnesis of long tobacco smoking, who have died from the external reasons. Positive immunohistochemical reaction to MMP-2, MMP-9 and their fabric TIMP-1 and TIMP-2 inhibitors have been received in control group and group of smokers (Table 3). The maximum intensity of the immunohistochemical reactions reflecting the content of proteinases and their inhibitors is found in intima and adventitia of cerebral arteries of persons with the anamnesis of long tobacco smoking. The dysbalance of MMP/ TIMP-system can have significant effect on structure and quality of a vascular wall. Increasing of MMP-2 and -9 with combination of decreasing their tissue inhibitors (TIMP-1 and -2) indicates an intensification of a proteolysis and degradation of collagen and elastic fibers in artery, including a basal membrane. These changes lead to the progressing loss the elastic properties of arterial wall, promotes to more vulnerable to a local haemodynamic stress in combination with pathological vasomotor activity of arteries at tobacco smoking.

Thus, physiological processes of extracellular matrix regeneration in brain arteries are mainly stimulated by MMP-2, MMP-9, TIMP1 and TIMP-2, and their dynamic balance helps to maintain the optimum level of tissue metabolism. TS induces MMP-2 and MMP- 
9 expression in cerebral arteries with reducing concentration of its tissue inhibitor that results in significant fluctuations of MMP/TIMP values. Dysregulation accompanying these processes leads to the
BBB destruction, thus, increasing the complications risk in case of smoking.

Table 3 The content of matrix metalloproteinases and their tissue inhibitors in cerebral arteries at smoking.

\begin{tabular}{llcc}
\hline Marker & Control group & Smokers & p-Level \\
\hline MMP-2, ODP & $47.51 \pm 21.42$ & $83.70 \pm 23.45$ & $\mathrm{P}<0.00 \mathrm{I}$ \\
MMP-9, ODP & $31.23 \pm 9.53$ & $57.21 \pm 17.39$ & $\mathrm{P}<0.00 \mathrm{I}$ \\
TIMP-I, ODP & $19.83 \pm 7.51$ & $10.34 \pm 4.50$ & $\mathrm{P}<0.001$ \\
TIMP-2, ODP & $44.32 \pm 19.66$ & $27.06 \pm 13.37$ & $\mathrm{P}<0.01$ \\
\hline
\end{tabular}

MMP-2, matrix metalloproteinase-2; MMP-9, matrix metalloproteinase-9; TIMP-I, tissue inhibitors of matrix metalloproteinases-I;TIMP-2, tissue inhibitors of matrix metalloproteinases-2; ODP, optical density of precipitate

\section{Conclusion}

Airflow obstruction is associated with increasing of cardiovascular morbidity and mortality. COPD patients with and without the established cardiovascular diseases with decline of expiratory flow has been connected with bigger prevalence, degree and gravity of atherosclerosis. Therefore, estimating cardiovascular risk at COPD patients, it is necessary to consider not only a contribution of traditional risk factors, but also value of FEV1. At the same time, measurement of the carotid intima-media thickness has to be used for assessment of cardiovascular risk at patients with COPD. Dysbalance in system of matrix metalloproteinases and their tissue inhibitors makes an additional contribution to increase of risk the cerebrovascular damage in COPD and smoking patients.

\section{Acknowledgments}

Study was supported by grant of Russian Science Foundation No. 14-33-00009-P.

\section{Conflicts of interest}

The authors declare no conflicts of interest.

\section{References}

1. Sin DD, Man SF. Chronic obstructive pulmonary disease as a risk factor for cardiovascular morbidity and mortality. Proc Am Thorac Soc. 2005;2(1):-811.

2. Maclay JD, MacNee W. Cardiovascular disease in COPD: mechanisms Chest. 2013;143(3):798-807.

3. Michiel JB, Peter JK, Albert $\mathrm{H}$, et al. Transcranial doppler hemodynamic parameters and risk of stroke: the Rotterdam study. Stroke. 2007;38(9):2453-2458.

4. Grant EG, Benson CB, Moneta GL, et al. Carotid artery stenosis: grayscale and Doppler US diagnosis - Society of Radiologists in Ultrasound Consensus Conference. Radiology. 2003;229(2):340-346.

5. Barr RG, Ahmed FS, Carr JJ, et al. Subclinical atherosclerosis, airflow obstruction and emphysema: the MESA Lung Study. Eur Respir J. 2012;39(4):846-854.

6. Iwamoto H, Yokoyama A, Kitahara Y, et al. Airflow limitation in smokers is associated with subclinical atherosclerosis. Am J Respir Crit Care Med. 2009;179(1):35-40.

7. Lahousse L, van den Bouwhuijsen QJ, Loth DW, et al. Chronic obstructive pulmonary disease and lipid core carotid artery plaques in the elderly: the Rotterdam Study. Am J Respir Crit Care Med. 2013;187(1):58-64.

8. Schroeder EB, Welch VL, Evans GW, et al. Impaired lung function and subclinical atherosclerosis. The ARIC Study. Atherosclerosis. 2005;180(2):367-373.

9. Mazzone P, Tierney W, Hossain M, et al. Pathophysiological impact of cigarette smoke exposure on the cerebrovascular system with a focus on the blood-brain barrier: expanding the awareness of smoking toxicity in an underappreciated area. Int J Environ Res Public Health. 2010;7(12):4111-4126.

10. Cunningham LA, Wetzel M, Rosenberg GA. Multiple roles for MMPs and TIMPs in cerebral ischemia. Glia. 2005;50(4):329-339.

11. Candelario-Jalil E, Yang Y, Rosenberg GA. Diverse roles of matrix metalloproteinases and tissue inhibitors of metalloproteinases in neuroinflammation and cerebral ischemia. Neuroscience. 2009;158(3):983-994.

12. Chindhi S, Thakur S, Sarkar M, et al. Subclinical atherosclerotic vascular disease in chronic obstructive pulmonary disease: Prospective hospital-based case control study. Lung India. 2015;32(2):137-141.

13. Ambrosino P, Lupoli R, Cafaro G, et al. Subclinical carotid atherosclerosis in patients with chronic obstructive pulmonary disease: a meta-analysis of literature studies. Annals of Medicine. 2017;49(6):513-524.

14. Suwa T, Hogg JC, Quinlan KB, et al. Particulate air pollution induces progression of atherosclerosis. J Am Coll Cardiol. 2002;39(6):935-942.

15. Zakharchuk NV, Nevzorova VA, Chertok VM, et al. Effects of chronic tabacco smoking on the cerebral blood flow. ZhNevrol PsikhiatrIm S SKorsakova. 2017;117(2):124-129.

16. Barnoya J, Glantz SA. Cardiovascular effects of secondhand smoke: nearly as large as smoking. Circulation. 2005;111(20):2684-2698.

17. Kool M, Hoeks A, Struijker Boudier HA, et al. Short- and long-term effects of smoking on arterial wall properties in habitual smokers. Journal of the American College of Cardiology. 1993;22(7):1881-1886.

18. Macnee W, Maclay J, McAllister D. Cardiovascular Injury and Repair in Chronic Obstructive Pulmonary Disease. Proc Am Thorac Soc. 2008;5(8):824-833

19. Rempe RG, Hartz AM, Bauer B. Matrix metalloproteinases in the brain and blood-brain barrier: Versatile breakers and makers. J Cereb Blood Flow Metab. 2016;36(9):1481-1507.

20. Lakhan SE, Kirchgessner A, Tepper D, et al. Matrix metalloproteinases and blood-brain barrier disruption in acute ischemic stroke. Front Neurol. 2013;4:32-56. 